\title{
Review: Effect Size Model Mastery Learning dalam Pembelajaran Kimia
}

\author{
Rizkiana Nurazizah \\ Pendidikan Kimia, Universitas Negeri Surabaya \\ Email: rizkiana.17030194056@mhs.unesa.ac.id \\ Rinaningsih Rinaningsih \\ Pendidikan Kimia, Universitas Negeri Surabaya \\ Email: rinaningsih@unesa.ac.id
}

(Diterima: 3-Januari-2021; direvisi: 4-Februari-2021; dipublikasikan: 21-Maret-2021)

\begin{abstract}
Abstrak: Penelitian ini bertujuan untuk mengidentifikasi effect size model mastery learning dalam pembelajaran kimia. Penulisan artikel review ini menggunakan desain penelitian meta analisis dengan menggunakan metode Glass. Dilakukan uji effect size dengan perbandingan hasil 5 literatur penelitian yang relevan. Dalam penelitian ini menggunakan teknik purposive sampling untuk memperoleh sampel. Berdasarkan uji effect size, diperoleh nilai effect size pada pembelajaran kimia dengan model mastery learning diantaranya yaitu 1) hasil belajar sebesar 1,32. 2) aktivitas belajar yang ditunjukkan dengan kreativitas peserta didik sebesar 4 dan aktivitas peserta didik sebesar 0,48. 3) respon peserta didik yang ditunjukkan dengan minat dan motivasi belajar peserta didik yaitu sebesar 21,98 dan 0,75. 4) peserta didik lakilaki memiliki nilai effect size lebih besar daripada peserta didik perempuan yaitu 24,53 dan 22,77. Hasil belajar peserta didik dapat meningkat dengan menggunakan model mastery learning. Peserta didik memiliki respon positif terhadap model mastery learning ditunjukkan dengan peserta didik sangat antusias, kritis dan lebih mudah memahami materi yang diajarkan.
\end{abstract}

Kata kunci: Effect Size; Mastery Learning; Pembelajaran Kimia.

Abstract: This review article aims to identify the effect size of the mastery learning model in chemistry learning. The writing of this review article uses a meta-analysis research design using the Glass method. An effect size test was performed with a comparison of the result of 5 relevant research literature. In this study using purposive sampling technique to obtain samples. Based on the effect size test, the effect size value obtained in chemistry learning with the mastery learning model includes 1) learning outcomes of 1.32.2) learning activities shown by the creativity of students by 4 and activities of studens by $0,48.3$ ) the response of students as indicated by the interest and motivation of learning students, namely 21,98 and 0,75 . 4) male students have a greater effect size than female students, namely 24,53 and 22,77. Student learning outcomes can be increased by using the mastery learning model. Students have a positive response to the mastery learning model indicated by students are very enthusiastic, critical and easier to understand the material being taught.

Keywords: Effect Size; Mastery Learning; Chemistry Learning.

\section{PENDAHULUAN}

Kimia merupakan salah satu materi pembelajaran yang wajib bagi peserta didik jurusan IPA di sekolah menengah atas (Agustina et al., 2012). Ilmu kimia merupakan ilmu yang mempelajari struktur materi dan perubahan-perubahan yang dialami materi dalam fenomena alamiah maupun dalam eksperimen (keenan, 1986). Oleh karena itu, peserta didik harus mampu 
memenuhi kompetensi dasar dalam pembelajaran kimia.

Pada proses pembelajaran kimia tidak jarang peserta didik mengalami kesulitan belajar karena bersifat teoritis. Hal ini mengakibatkan peserta didik kesulitan mempelajari konsep materi kimia secara komprehensif sehingga peserta didik cenderung menghafal dan mengerjakan soalsoal kimia secara mekanistik tanpa memahami materi dasar. Hal ini mengakibatkan skema pemikiran peserta didik terpisah. Apabila permasalahan tersebut dibiarkan akan mengakibatkan peserta didik menjadi kurang aktif saat pembelajaran kimia berlangsung.

Kesulitan belajar mengakibatkan penurunan hasil belajar pada mata pelajaran kimia. Kesulitan belajar diantaranya minat belajar yang rendah, lingkungan belajar yang kurang kondusif dan respon kognitif peserta didik yang rendah. Dalam suatu kelas, peserta didik memiliki gaya belajar yang bervariasi (Rinaningsih et al., 2018). Hal ini dapat mengakibatkan tingkat kesulitan yang berbeda-beda pada setiap peserta didik. Apabila kesulitan belajar tidak ditindaklanjuti akan mengakibatkan hasil belajar peserta didik tidak memenuhi KKM yang ditetapkan. Dalam menghadapi kesulitan belajar peserta didik, guru perlu melakukan model belajar yang dapat mengantarkan peserta didik mencapai kompetensi dasar dalam pembelajaran kimia. Salah satu model pembelajaran yang dapat mengatasi kesulitan belajar yaitu model mastery learning. Model mastery learning cenderung meningkatkan prestasi dalam pembelajaran sains (Guskey \& Gates, 1986).

Model belajar tuntas (mastery learning) merupakan model pembelajaran yang bertujuan peserta didik untuk mencapai suatu tingkat penguasaan yang telah ditetapkan oleh suatu unit pelajaran tertentu. Peserta didik memiliki usia yang sama kemungkinan memiliki struktur kognitif yang berbeda. Hal ini mengakibatkan adanya proses pembelajaran yang berbeda pada setiap peserta didik (Rinaningsih, 2014). Dalam belajar tuntas diberlakukan remedial yang bertujuan untuk memperbaiki kesulitan belajar yang dihadapi peserta didik saat mempelajari materi (Rusmin, 2016). Dengan demikian, peserta didik memiliki tingkat penguasan pengetahun dan kemampuan diatas kriteria yang ditentukan. Peserta didik yang dinyatakan tuntas dapat melanjutkan unit pembelajaran berikutnya. Sebaliknya, peserta didik yang belum tuntas mencapai standar kompetensi yang disepakati maka peserta didik harus melakukan remedial untuk perbaikan materi (Istiarsono, 2019).

Model mastery learning lebih baik dalam mencapai ketuntasan belajar daripada model pembelajaran konvensional (Fitri et al., 2016). Pemahaman konsep materi pembelajaran lebih mudah diterima peserta didik dengan menggunakan model mastery learning (Lediana, 2017). Dengan menggunakan model mastery learning hasil belajar peserta didik akan meningkat (basri et al., 2014). Peserta didik yang awalnya memiliki pengetahuan yang rendah dapat meningkatkan hasil belajar, jika pembelajaran yang dilakukan melalui model mastery learning (Block, 1971). Model mastery learning mengarahkan peserta didik terhadap proses belajar yang lebih baik (Wambugu \& Changeiywo, 2018). Model mastery learning mempertahankan pemahaman materi yang konstan dan memungkinkan waktu pembelajaran yang bervariasi. Sedangkan, model pembelajaran konvensional mempertahankan waktu yang konstan dan memungkinkan pemahaman materi yang bervariasi (Ozden, 2008). Pembelajaran konvensional mengakibatkan peran guru sangat dominan di dalam kelas, peserta didik kurang aktif dan suasana kelas terkesan sunyi (Ghultom et al., 2016).

Artikel review ini bertujuan untuk mengidentifikasi effect size model mastery learning dalam pembelajaran kimia. Hasil tinjauan dari beberapa studi literatur disusun penulis berupa artikel review yang membandingkan hasil penggunaan model mastery learning dalam pembelajaran kimia. Pertanyaan tersebut akan dianalis dan dilakukan pembahasan pada artikel review 
ini yaitu "Bagaimana effect size mastery learning dalam pembelajaran kimia?".

\section{METODE}

Penulisan artikel review ini menggunakan desain penelitian meta analisis. Meta analisis merupakan metode penelitian menggunakan data sekunder yang dilakukan secara sistematis dan kuantitatif untuk memperoleh kesimpulan yang akurat (Retnawati et al., 2018). Metode penelitian meta analisis yang digunakan yaitu metode Glass. Dalam perhitungan ini dilakukan melalui uji effect size dengan perbandingan hasil 5 literatur penelitian yang relevan. Dalam penelitian ini menggunakan teknik purposive sampling untuk memperoleh sampel. Purposive sampling merupakan suatu teknik untuk memperoleh data dengan kriteria tertentu (Sugiyono, 20). Hal ini dikarenakan data yang ingin diperoleh dari sampel ditentukan berdasarkan topik artikel review ini. Data penelitian bersumber dari artikel ilmiah, skripsi dan Textbook. Pencarian literatur dengan menentukan kata kunci berupa mastery learning dan kimia. Studi literatur menggunakan database google scholar, researchgate dan science direct.

Langkah-langkah perhitungan data yaitu 1) mengidentifikasi subjek penelitian, 2) mengidentifikasi mean dan standar deviasi dari data eksperimen dan data kontrol pada setiap subjek penelitian, 3) melakukan perhitungan effect size dengan menggunakan rumus Glass. Pengukuran effect size dengan rumus Glass dilakukan sebagai berikut (Asror, 2016):

\section{Mean eksperimen grup - Mean kontrol grup} Standard deviasi kontrol grup

\section{HASIL DAN PEMBAHASAN}

Model mastery learning berazaskan pada ketuntasan belajar (Rumitaningsih, 2020). Model mastery learning berpegang pada prinsip perbedaan individual peserta didik sehingga peserta didik lebih aktif saat pembelajaran berlangsung (Ghultom et al., 2016). Dalam model mastery learning, peserta didik memiliki waktu dan kesempatan belajar yang sesuai dengan keadaan sehingga peserta didik dapat mencapai kompetensi dasar pada materi pembelajaran dengan cara dan kecepatan yang berbeda-beda (Adhi, 2017). Apabila peserta didik tertinggal dalam pembelajaran kimia, maka peserta didik diberi tindakan untuk mengejar ketertinggalan pada penguasaan materi (Suartini, 2019). Model pembelajaran ini mengharapkan setiap peserta dapat menguasai materi pembelajaran, maka hasil belajar harus tuntas dalam suatu unit pembelajaran sebelumnya dan melanjutkan ke unit pembelajaran berikutnya (Rifai et al, 2016). Peserta didik yang belum tuntas melalukan pembelajaran remediasi untuk meningkatkan prestasi belajar, sehingga dapat mencapai ketuntasan belajar yang telah ditetapkan (Rinaningsih, 2019). Model mastery learning berasumsi bahwa dalam kondisi yang tepat, semua peserta didik dapat belajar dengan baik dan memperoleh hasil belajar yang maksimal pada materi yang dipelajari (GukGuk, 2018). Model mastery learning mendukung kepercayaan diri peserta didik dapat belajar dengan baik dan mencapai kompetensi dasar (Groen et al, 2015). Dengan demikian, daya serap peserta didik meningkat dengan mencapai KKM yang telah ditetapkan (Harmin et al, 2019) (Hasibuan, 2019).

Pengaruh penggunaan model mastery learning dalam pembelajaran kimia dibuktikan melalui study effect size. Study effect size tersebut dilakukan dengan membandingkan lima literatur penelitian yang relevan. Lima hasil literatur penelitian yang diuji effect size diantaranya Ansar (2012); Degi alrinda agustina, Muntari \& Munti'ah (2012); Mfon Effiong Udo \& Theresa Maurice Udofia (2014); Nasir sah (2016); dan Rima Yulia Fitri (2020). Distribusi subjek penelitian dapat dilihat pada Tabel 1.

Tabel 1. Distribusi Subjek Penelitian Berdasarkan 5 Literature Relevan pada Model Mastery Learning dalam Pembelajaran Kimia 


\begin{tabular}{|c|c|c|c|c|c|}
\hline \multirow[b]{2}{*}{ Penulis } & \multirow[b]{2}{*}{ Keterangan } & \multicolumn{4}{|c|}{ Subjek Penelitian } \\
\hline & & $\begin{array}{l}\text { Hasil Belajar } \\
\text { Kimia }\end{array}$ & $\begin{array}{l}\text { Aktivitas } \\
\text { Belajar }\end{array}$ & $\begin{array}{c}\text { Respon } \\
\text { Peserta } \\
\text { Didik } \\
\end{array}$ & $\begin{array}{c}\text { Jenis } \\
\text { Kelamin }\end{array}$ \\
\hline Ansar (2012) & $\begin{array}{l}\text { Motivasi } \\
\text { Hasil belajar }\end{array}$ & $\sqrt{ }$ & & $\sqrt{ }$ & \\
\hline Mfon Effiong & Minat & & & $\sqrt{ }$ & \\
\hline Udo \& Theresa & Hasil belajar & $\sqrt{ }$ & & & \\
\hline $\begin{array}{l}\text { Maurice Udofia } \\
\text { (2014) }\end{array}$ & Jenis kelamin & & & & $\sqrt{ }$ \\
\hline Nasir sah (2016) & Kreativitas & & $\sqrt{ }$ & & \\
\hline Rima Yulia Fitri & Aktivitas siswa & & $\sqrt{ }$ & & \\
\hline (2020) & Hasil belajar & $\sqrt{ }$ & & & \\
\hline $\begin{array}{l}\text { Degi alrinda } \\
\text { agustina, } \\
\text { Muntari \& } \\
\text { Munti'ah (2012) }\end{array}$ & Hasil belajar & $\sqrt{ }$ & & & \\
\hline
\end{tabular}

Berdasarkan Tabel 1, dilakukan uji effect size pada setiap subjek penelitian. Dari hasil effect size tersebut dapat dianalisis mengenai pengaruh model mastery learning dalam pembelajaran kimia. Pengaruh model mastery learning dalam pembelajaran kimia dapat dinyatakan pada Tabel 2, Tabel 3, Tabel 4, dan Tabel 5.

Tabel 2. Besar Pengaruh Mastery Learning terhadap Hasil Belajar Peserta Didik pada Pembelajaran Kimia

\begin{tabular}{ccccc}
\hline Subjek Penelitian & Mean & Standar Deviation & Effect Size & Kriteria \\
\hline Hasil Belajar & 32,35 & 24,37 & 1,32 & $\begin{array}{c}\text { Efek yang } \\
\text { sangat tinggi }\end{array}$ \\
\hline
\end{tabular}

Tabel 3. Besar Pengaruh Mastery Learning terhadap Aktivitas Belajar pada Pembelajaran Kimia

\begin{tabular}{ccccc}
\hline Subjek Penelitian & Mean & Standar Deviation & Effect Size & Kriteria \\
\hline Aktivitas siswa & 10,57 & 21,84 & 0,48 & $\begin{array}{c}\text { Efek sedang } \\
\text { Krengaruh yang } \\
\text { tinggi }\end{array}$ \\
\hline
\end{tabular}

Tabel 4. Besar Pengaruh Mastery Learning terhadap Respon Peserta Didik pada Pembelajaran Kimia

\begin{tabular}{ccccc}
\hline Subjek Penelitian & Mean & Standar Deviation & Effect Size & Kriteria \\
\hline Minat & 60,01 & 2,73 & 21,98 & $\begin{array}{c}\text { Pengaruh yang } \\
\text { tinggi } \\
\text { Motivasi }\end{array}$ \\
\hline
\end{tabular}

Tabel 5. Besar Pengaruh Mastery Learning terhadap Jenis Kelamin Peserta Didik pada Pembelajaran Kimia

\begin{tabular}{ccccc}
\hline Subjek Penelitian & Mean & Standar Deviation & Effect Size & Kriteria \\
\hline Perempuan & 58,77 & 2,58 & 22,77 & Pengaruh yang \\
\hline
\end{tabular}


Nurazizah, Rinaningsih. Review: effect size....

\begin{tabular}{ccccc}
\hline Subjek Penelitian & Mean & Standar Deviation & Effect Size & Kriteria \\
\hline Laki-laki & 64,28 & 2,62 & 24,53 & $\begin{array}{c}\text { Pengaruh yang } \\
\text { tinggi }\end{array}$ \\
\hline
\end{tabular}

Berdasarkan Tabel 2 diatas, model mastery learning memiliki pengaruh besar dalam meningkatkan hasil belajar pada pembelajaran kimia. Hal ini ditunjukkan dengan hasil uji effect size sebesar 1,32 dan masuk dalam kriteria efek yang sangat tinggi. Hasil belajar peserta didik dapat meningkat dengan menggunakan model mastery learning (Ghultom et al., 2016) (Muhtar, 2016) (Zulisyanto, 2018) (Martono, 2019). Hal ini dikarenakan setiap peserta didik dapat kegiatan pembelajaran dengan baik dalam kondisi yang sesuai dan mendapatkan hasil belajar yang maksimal terhadap seluruh materi (As-syakir, 2017). Pencapaian tersebut berdasarkan peningkatan hasil belajar pada siklus yang diterapkan dalam model mastery learning (Ilmi, 2016) (Ginting, 2017). Model mastery learning dapat dinyatakan sebagai alternatif untuk meningkatkan hasil belajar dalam pembelajaran kimia (Darmavandi \& Zahra, 2010).

Berdasarkan Tabel 3 diatas, menunjukkan bahwa hasil uji effect size pada aktivitas belajar dalam pembelajaran kimia dengan model mastery learning yaitu aktivitas peserta didik sebesar 0,48 dan kreativitas peserta didik sebesar 4. Aktivitas peserta didik dalam pembelajaran kimia dengan model mastery learning memiliki efek sedang. Kreativitas peserta didik dalam pembelajaran kimia dengan model mastery learning menunjukkan pengaruh yang tinggi.

Peningkatan hasil belajar peserta didik diimbangi dengan meningkatnya aktivitas belajar di kelas. Adanya model mastery learning dapat memotivasi peserta didik untuk lebih aktif dalam belajar seperti bertanya, membaca, mencatat dan mengerjakan soal serta aktivitas guru dalam mengajar turut meningkat (Novelia et al., 2017) (Watiningsih, 2020) (SetiawatI \& Syaf, 2018). Keefektifan suatu pembelajaran ditunjang oleh interaksi antara guru dan peserta didik (Rinaningsih, 2014). Model mastery learning dapat dilakukan melalui tutor sebaya untuk memudahkan dalam memahami dan menerapkan materi yang dipelajari (Arusman, 2019) (Muhidi et al., 2019) (Perthami, 2019). Hal ini dapat dilakukan dengan diskusi kelompok antara peserta didik yang telah memahami materi dan peserta didik yang memiliki pemahaman materi yang kurang (Rinaningsih et al., 2018). Model mastery learning melalui tutor sebaya sangat efektif dalam memecahkan masalah pembelajaran (Parwati, 2019).

Berdasarkan Tabel 4 diatas, Peserta didik memiliki respon yang sangat baik terhadap model mastery learning. Hal ini ditunjukkan minat peserta didik dalam pembelajaran kimia dengan model mastery learning memiliki effect size sebesar 21,98. Effect size motivasi peserta didik dalam pembelajaran kimia dengan model mastery learning sebesar 0,75. Adanya model mastery learning dalam pembelajaran kimia, peserta didik merasa senang dan lebih mudah mempelajari materi sehingga lebih termotivasi dalam belajar (Fitri et al., 2016) (Dahliani, 2019) (Saparudin, 2019). Dengan demikian, peserta didik mampu untuk menyatakan dan memperbaiki kekurangan dalam belajar (Bustami et al., 2016). Model mastery learning mengakibatkan peserta didik sangat antusias, kritis dan dapat memahami materi yang diajarkan (Mulyadi, 2019).

Berdasarkan Tabel 5 diatas, adanya pengaruh mastery learning terhadap jenis kelamin peserta didik pada pembelajaran kimia. Effect size peserta didik perempuan pada pembelajaran kimia dengan model mastery learning sebesar 22,77. Sedangkan, Effect size peserta didik laki- laki pada pembelajaran kimia dengan model mastery learning sebesar 24,53. Peserta didik perempuan memiliki nilai effect size lebih 
rendah daripada laki-laki dalam pembelajaran kimia dengan model mastery learning.

Dalam upaya mencapai ketuntasan belajar pada pembelajaran kimia dapat menggunakan model mastery learning. Model mastery learning dapat meningkatkan aktivitas belajar baik peserta didik. Model mastery learning memberikan respon positif bagi peserta didik. Hal ini menunjukkan bahwa model mastery learning dapat sebagai alternatif dalam mencapai ketuntasan belajar (Komariah, 2018) (Ismawati, 2020).

\section{SIMPULAN DAN SARAN}

Berdasarkan hasil penelitian, maka kesimpulan dari penelitian ini adalah model mastery learning dalam pembelajaran kimia memiliki pengaruh diantaranya yaitu 1) model mastery learning memiliki efektivitas yang besar dalam meningkatkan hasil belajar peserta didik dalam pembelajaran kimia dengan nilai effect size sebesar 1,32 yang menunjukkan memiliki efek besar. 2) kreativitas peserta didik memiliki efektivitas lebih besar daripada aktivitas peserta didik pada pembelajaran kimia dengan model mastery learning yaitu sebesar 4 dan 0,48. Ini menunjukkan bahwa kreativitas peserta dalam pembelajaran kimia dengan model mastery learning memiliki efek besar. Sedangkan, aktivitas peserta didik dalam pembelajaran kimia dengan model mastery learning memiliki efek kecil. 3) Respon peserta didik sangat baik terhadap model mastery learning dalam pembelajaran kimia. Hal ini ditunjukkan dengan nilai effect size pada minat dan motivasi peserta didik pada pembelajaran kimia dengan model mastery learning yaitu sebesar 21,98 dan 0,75. 4) adanya pengaruh model mastery learning dalam pembelajaran kimia terhadap jenis, ini ditunjukkan dengan nilai effect size peserta didik laki-laki lebih besar daripada peserta didik perempuan yaitu sebesar 24,53>22,77.

Berdasarkan kesimpulan pada hasil penelitian, peneliti memberikan saran yaitu dalam pembelajaran kimia dapat disarankan menggunakan model mastery learning untuk meningkatkan hasil belajar peserta didik, model mastery learning dalam pembelajaran kimia dilaksanakan dengan baik dan benar agar tercapainya tujuan pembelajaran, dan perlu dilakukan penelitian lebih lanjut mengenai review model mastery learning dalam pembelajaran kimia untuk mengembangkan penelitian ini.

\section{DAFTAR RUJUKAN}

Adhi, I. S. (2017). Pengaruh Model Pembelajaran Mastery Learning Terhadap Keterampilan Menulis Kalimat Sederhana Bahasa Inggris Kelas 5 Sd Sono Parangtritis Kretek Bantul. E-Jurnal Prodi Teknologi Pendidikan. 6(1).

Agustina, D. A., Muntari, \& Munti'ah. (2012). Pengaruh Strategi Belajar Tuntas (Mastery Learning) terhadap Prestasi Belajar Kimia pada Materi Pokok Reaksi Redoks Kelas X Semester 2 SMA Hang Tuah 3 Mataram. J. Pijar Mipa. 8(1), 23-36.

Ansar. (2012). Peningkatan Motivasi dan Hasil Belajar Kimia Siswa Kelas X5 SMA Negeri 1 Gngking melalui Pembelajaran Tuntas. Jurnal Chemicavo. 11(1).

Arusman. (2019). Pengaruh Pendekatan Mastery Learning dengan Pola Kelompok Remedial terhadap Peningkatan Hasil Belajar Peserta Didik. Lantanida. 7(2).

As-syakir \& Rahman, A. (2017). Pengaruh Aktivitas Belajar Siswa dalam Strategi Belajar Tuntas (Mastery Learning) terhadap Hasil Belajar Siswa. PESAGI (Jurnal Pendidikan dan PenelitianSejarah). 5(4).

Asror A. H. (2016). Meta-analisis: PBL. Prosiding. PRISMA: Prosiding Seminar Nasional Matematika. 508513.

Basri, S., Karsadi, \& Jumareng, H. (2014). Pengaruh Model Pembelajaran Tuntas Terhadap Hasil Belajar Ekonomi. Jurnal Wahana Kajian Pendidikan IPS. 1(2).

Bustami, Yusrizal \& Adlim. (2016). Pengembangan Pendekatan Belajar 
Tuntas (Mastery Learning) Dengan Pola Kelompok Remedial Untuk Meningkatkan Ketuntasan dan Motivasi Belajar Fisika Pada Siswa Smpn 2 Sakti Kabupaten Pidie. Jurnal Pendidikan Sains Indonesia. 4(2), 1-5.

Block, J. H. (1971). Mastery Learning Theory and Practice. New York NY: Holt, Rinehart and Winston.

Dahliani, Sefrina. (2019). Meningkatkan kemampuan menulis surat resmi melalui metode pembelajaran tuntas siswa kelas VI/B SD Negeri 1 Sabang. Jurnal Ekonomi. Pendidikan dan Sains. 3(1), 25-34.

Damavandi, M. E. \& Zahra S. K. (2010). Effect of Mastery Learning Methode on Performance and Attitude of The Weak Student in Chemistry. Procedia Social and Behavioral Sciences. 5, 1574-1579.

Fitri, Hesti, dan WF, Nurul S. (2016). Pengaruh Model pembelajaran Tuntas (Mastery Learning) Terhadap Hasil Belajar Siswa pada Materi Pelajaran Ekonomi (Studi Eksperimen kuasi pada Kelas X di SMA Negeri 1 Palimanan Kabupaten Cirebon). Jurnal Logika. 17(2).

Fitri, Rima, Y. (2020). Penerapan Model Pembelajaran Mastery Learning terhadap Hasil Belajar Siswa pada Materi Ikatan Kimia di SMA Negeri 1 Samadua Aceh Selatan. Skripsi. Banda Aceh: Prodi Pendidikan Kimia, Fakultas Tarbiyah dan Keguruan, UIN Ar-Raniry Banda Aceh.

Ginting, S. (2017). Penerapan Metode Mastery Learning dalam Meningkatkan Hasil Belajar Pendidikan Agama Kristendi Kelas V SDN 165728 Tebing Tinggi. Jurnal kajian Dasar dan Pendidikan Dasar. 7(2).

Ghultom, K., \& Putra, J.D. (2016). Pengaruh Penerapan Model Mastery Learning terhadap Hasil Belajar Matematika Siswa Kelas VII SMPN 10 Batam
Tahun Pelajaran 2014/2015. Phytagoras. 5(1), 74-79.

Guskey, T. \& Gates, S. 1986. Synthesis of Research on the Effects of Mastery Learning in Elementary and Secondary Classroms. Educational Leadership. 43(8), 73-80.

Groen, Layna. et al. (2015). The mathematics Problem and Mastery Learning for First Year, Undergraduate STEM Students. International Journal of Learning, Teaching and Educational Research. 141-160.

GukGuk, Tiorim Raja. (2018). Penerapan Model Pembelajaran Tuntas Untuk Meningkatkan Ketuntasan Hasil Belajar Siswa Pada Materi Volume Kubus dan Balok di Kelas V Sd Negeri 137524 Tanjungbalai. Jurnal Ilmiah Kohesi. 2(4).

Harmin, Vina Rosalina., Murniasih, Ni Nyoman \& Suana, I W. (2019). Penerapan Model Pembelajaran Mastery Learning dengan Tutor Sebya dalam Meningkatkan Prestasi Belajar Ekonomi Peserta Didik Kelas $X$ IPS 3 SMA PGRI 2 Denpasar Tahun Ajaran Pelajaran 2017/2018.

Hasibuan, Ferawati A. \& Hutabarat, Henry Dinus. (2019). Penerapan Model Pembelajaran Mastery Learning untuk Meningkatkan Kemampuan Merumuskan Hipotesis Fisika Siswa Kelas XI SMA NEGERI 3 SIBOLGA. PeTeKa (Jurnal Penelitian Tindakan Kelas dan Pengembangan Pembelajaran). 2(1), 22-29.

Ilmi, S. (2016). Penerapan Strategi Belajar Tuntas (Mastery Learning) untuk Pencapaian Standar Kompetensi dalam Pelajaran ekonomi di SMA IT Yapira Medang Kabupaten Bogor. 5(1), 12-27.

Keenan. 1986. Kimia Dasar Prinsip dan Terapan Modern Edisi Keempat. Jakarta: Erlangga.

Komariah, E. (2018). Meningkatkan Prestasi Belajar Aqidah Akhlak Melalui 
Penerapan Model Pembelajaran Mastery Learning (Belajar Tuntas) Di Kelas Vii Mts Al-Hajar. Jurnal Penelitian Guru FKIP Universitas Subang. 1(2).

Lediana. (2017). Pengaruh Pendekatan Mastery Learning Terhadap Pemahaman Konsep Matematis Self Confidence peserta didik kelas VII SMPN 24 Bandar Lampung. Undergraduate thesis. Lampung: Prodi Pendidikan Matematika, Fakultas Tarbiyah dan Keguruan, UIN Raden Intan Lampung.

Martono, S. M. (2019). Pengembangan Perangkat Pembelajaran dengan Strategi Tuntas untuk Meningkatkan Hasil Belajar. SOSCIED. 2(1).

Muhtar, Edi Mohamad. (2016). Penerapan Model Pembelajaran Mastery Learning untuk Meningkatkan Hasil Belajar PKN Siswa Kelas V SD Negeri 017 Bagan Limau Kecamatan Ukui. Jurnal Primary Program Studi Pendidikan Guru Sekolah Dasar Fakultas Keguruan dan Ilmu Pendidikan Universitas Riau. 5(3).

Muhidin, Aeng. dkk. (2019). Pengembangan Pembelajaran Mastery Learning pada Mata Kuliah Statistika Pendidikan. Jurnal Teknologi Pendidikan. 21(1).

Mulyadi, I Nyoman. (2019). Penerapan Model Pembelajaran Mastery Learning Untuk Meningkatkan Prestasi Belajar Matematika Siswa Kelas IXB SMP Negeri 3 Selat. Cetta: Jurnal Ilmu Pendidikan. 2(2).

Novelia, R., Rahimah, D. S. M., \& Fachruddin. (2017). Penerapan Model Mastery Learning Berbantuan LKPD untuk Menngkatkan Hasil Belajar Matematika Peserta Didik di Kelas VII.3 SMP Negeri 4 Kota Bengkulu. Jurnal Penelitian Pemb. Matematika Sekolah (JP2MS). 1(1).

Ozden, M. (2008). Improving Science and Technology Education Achievement Using Mastery Learning Model. World Applied Sciences Journal. 5, 1818-4952.
Perthami, Ni Wayan. (2019). Model Pembelajaran Mastery Learning dengan Strategi Tutor Sebaya untuk Meningkatkan Prestasi Belajar IPA. Jurnal Santiaji Pendidikan. 10(1).

Retnawati, H. dkk. (2018). Pengantar Analisis Meta. Yogyakarta: parama publishing.

Rusmitaningsih, F., \& Nuraini. (2020). Penerapan Program System Block Mastery Learning untuk Meningkatkan Hasil Belajar Renang Gaya Dada. Jurnal Penelitian Pendidikan Indonesia (JPPI). 5(2).

Rusmin, B. (2016). Belajar Tuntas. Makassar: Universitas Islam Negeri Alauddin.

Rinaningsih. (2014). Implementasi Model Perkuliahan Terpadu SoroganBandongan untuk Menentukan Pemahaman Mahasiswa dalam Mempelajari Mekanisme Reaksi. Jurnal Pengajaran MIPA. 2(19), 266-274.

Rinaningsih et al. (2018). Profile of Students Learning Styles in SoroganBandongan Organic Chemistry Lecture. Journal of Physics: Coference Series.

Rinaningsih et al. (2018). Aplication Sorogan-Bandongan Model in Lectures Reaction Mechanism. ATLANTIS PRESS: Advances in Engineering Research. (171).

Sah, N. (2016). Penerapan Model Pembelajaran Tuntas (Mastery Learning) untuk Meningkatkan Kreativitas Belajar Kimia Siswa melalui di SMA Negeri 3 Padangsidimpuan. Nusantara: Jurnal Ilmu Pengetahuan Sosia. 1.

Sahari. (2020). Meningkatkan Prestasi Belajar Akidah Akhlak Melalui Penerapan Model Pembelajaran Mastery Learning bagi Siswa MTs. Hidayaturrahman NW Menggala. Jurnal Paedagogy: Jurnal Penelitian dan Pengembangan Pendidikan. 7(4). 
Saparudin. (2019). Meningkatan Hasil Belajar Biologi Melalui Model Mastery Learning Pada Siswa Kelas XII SMAN 8 Palembang. Edudikara: Jurnal Pendidikan dan Pembelajaran. 4(1).

Setiawati, Hismi, H., \& Syaf, A. H. (2018). Penerapan Model Mastery Learning dalam Meningkatkan Pemahaman matemtik Siswa. Journal of Islamic Primary Education. 1(2).

Suartini, Ni Kadek. 2019. Penerapan Model Pembelajaran Mastery Learning untuk Meningkatkan Prestasi Belajar Matematika Siswa Kelas IV SD Negeri 2 Seraya Barat. Cetta: Jurnal Ilmu Pendidikan. 2(3).

Sugiyono. (2016). Metode Penelitian Kuantitatif, Kualitatif dan Kombinasi (Mixed Method). Bandung: Alfabeta.

Udo, M. E. \& Udofia, T. M. (2014). Effect of Mastery Learning Strategy on Student'Achievement in Symbols, Formulae, and Equations in Chemistry. Journal of Educational Research and Reviews. 2(3).

Watiningsih, Y. U. 2020. Meningkatkan Motivasi dan Hasil Belajar PKN Melalui Penerapan Model Pembelajaran Tuntas Pada Siswa Kelas IV SD Negeri Kutorenon 03 Kecamatan Sukodono Lumajang Semester Genap Tahun 2018/2019. PITALOCA. 6(3).

Zulisyanto, D. (2018). Penerapan Model Belajar Tuntas (Mastery Learning) dalam meningkatkan Prestasi Belajar Peserta Didik MI Roudlotul Huda. Jurnal Profesi Keguruan. 